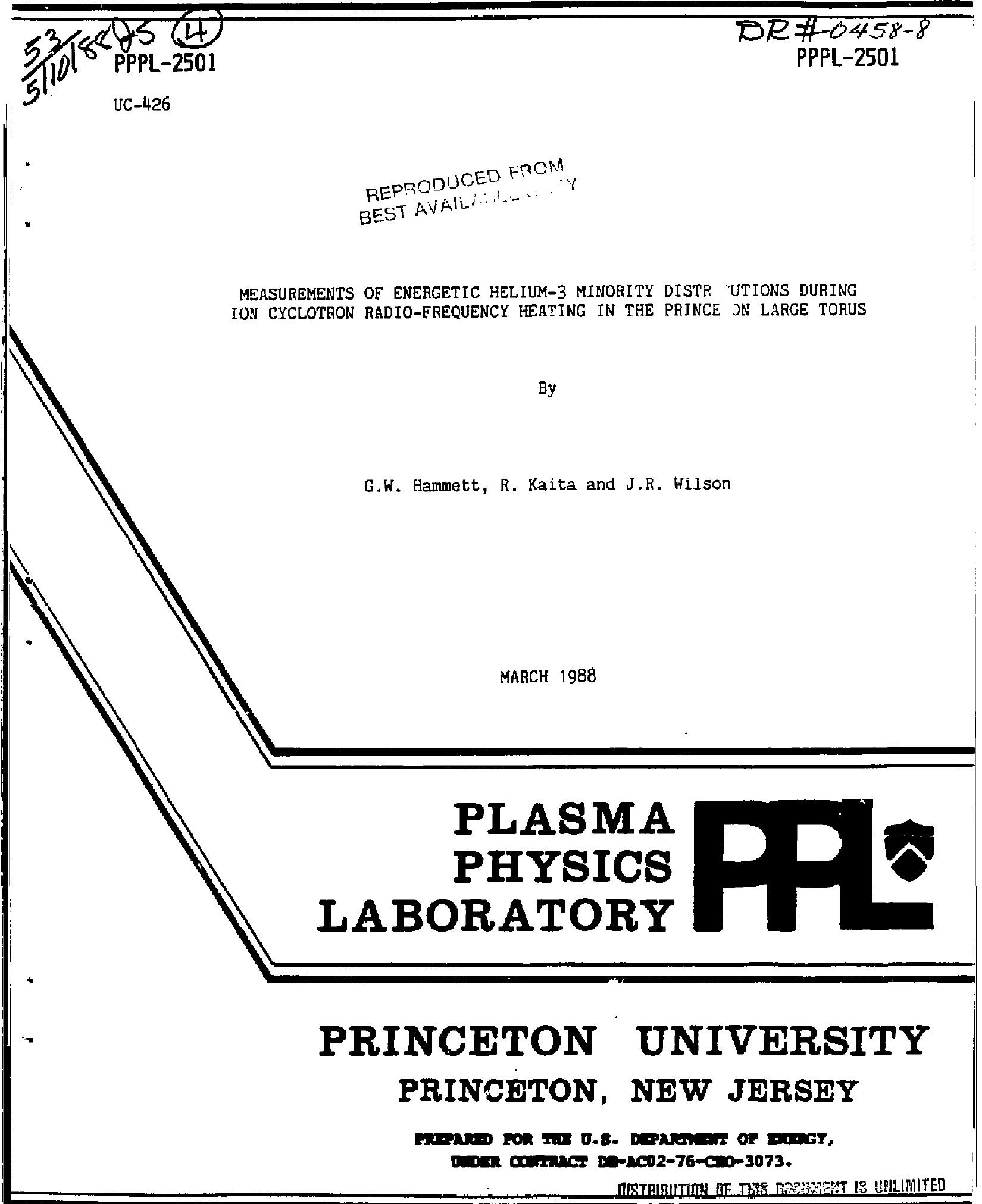


This report was prepared as an account of work sponsored by the United States Government. Neither the United Stateg nor the United States Department of Energy, nor any of their employees, nor any of their contractors, subcontractors, or their employees, makes any warzanty, express or implied, or assumes any legal liability or regponsibility for the accuracy, completeness or usefulness of any information, apparatus, product or process disclosed, or represents that its use wuld not infringe privately owned rights.

Printed in the United States of America

Avallable from:

National Technical Information Service

U. S. Department of Commerce

5285 Port Royal Road

Springfield, Virginia 22161

Prlce Printed Copy $\$$; Microfiche $\$ 4.50$

+Pages

$1-25$

25-50

$51-75$

76-100

$101-125$

$126-150$

$151-175$

$176-200$

$201-225$

226-250

251-275

276-300

$301-325$

326-350

$351-375$

$376-400$

$401-425$

426-450

$451-475$

476-500

500-525

526-550

$551-575$

567-600

HTIS

Selling Price

$\$ 7.00$

$\$ 8.50$

$\$ 10.00$

$\$ 11.50$

$\$ 13.00$

$\$ 14.50$

$\$ 16.00$

$\$ 17.50$

$\$ 19.00$

$\$ 20.50$

$\$ 22.00$

$\$ 23.50$

$\$ 25.00$

$\$ 26.50$

$\$ 28.00$

$\$ 29.50$

$\$ 31.00$

$\$ 32.50$

$\$ 34.00$

$\$ 35.50$

$\$ 37.00$

$\$ 38.50$

$\$ 40.00$

$\$ 41.50$
For documents over 600

pages, add $\$ 1.50$ for

each additional 25-page

increment. 


\section{MEASUREMENTS OE ENERGETIC HELIUM-3 MINORITY DISTRIBUTIONS DURING ION CYCLOTRON RADIO-EREQUENCY HEATING IN THE PRINCETON LARGE TORUS}

G.W. Hammett, R. Kaita, and J.R. Wilson

\section{Princeton Plasma Physles Laboratory Princeton, NJ 08544, USA}

\section{ABSTRACT}

Ion cyclotron radio-frequency heating experiments were performed with a ${ }^{3}$ e minority ion species in a ${ }^{4}$ He majority plasma in the Princeton Large Torus. The energetic 3He ion "tail" was measured directly witil a charge exchange neutral analyzer for the first time. Comparisons with bounce-averaged quasilirear calculations suggest a modestly peaked radio-frequency power deposition profile. The double charge exchange process ${ }^{3} \mathrm{He}^{++}+{ }^{4} \mathrm{He}^{\mathrm{O}}+{ }^{3} \mathrm{He}^{\mathrm{O}}+{ }^{4} \mathrm{He}^{++}$ demonstrated in these measurements may be useful as part of an alpha particle diagnostic in a fusion reactor experiment.

\section{NuSisTER.}


The most successful heating scheme in the. ion cyclotron range of frequencies (ICRF) in the Princeton Large Torus (PLT) has been in the ${ }^{3} \mathrm{He}$ minority, deuterium (D) majority regime $[1,2]$. With this radio-frequency (RE) heating method, it is difficult to observe the RF-produced 3 He tail using standard charge exchange techniques because most of the neutrals in the plasma are $D^{0}$, which have only one electron and cannot neutralize the ${ }^{3} \mathrm{He}^{++}$. Fusion product measurements of the $\mathrm{d}\left({ }^{3} \mathrm{He}\right.$, a) $/ \mathrm{p}$ reaction have been used previously to

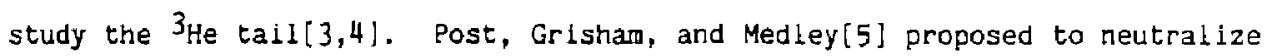
the energetic ${ }^{3} \mathrm{He}^{++}$by double charge exchange with ${ }^{4} \mathrm{He}^{0}$ from standard neutral beam injectors. A variant of this method using multi-MeV, $Z>2$ neutral beams has been proposed for detection of $3.5 \mathrm{MeV}$ alpha particles[6]. The double charge exchange process

$$
{ }^{3} \mathrm{He}^{++}+{ }^{4} \mathrm{He}^{0}-{ }^{3} \mathrm{He}^{0}+{ }^{4} \mathrm{He}^{++}
$$

has a fairly bigh cross section (only a factor of about 10 less than the usual $\mathrm{H}^{+}+\mathrm{H}^{0} \rightarrow \mathrm{H}^{0}+\mathrm{H}^{+}$cross section) because it is a resonant process. A hor $\mathrm{i}-$ zontally scanning, mass-resolving charge exchange neutral analyzer (CENA)[7] was used in the present study (Fig. 1). A vertically scanning mass-analyzed charge exchange diagnostic (MACE), also shown in the figure, was used in confunction with the CENA to determine the relative concentrations of the various ion species during fundamental minority and second harmonic majority ICRE heating[8;. Because the CENA was not oriented to look across the sightline of the existing neutral beam injectors on PLT, we decided to use $a$ passive charge exchange version of the Post-Grisham-Medley scheme. By making a 4 He majority plasma instead of a 0 majority plasma (both species having the same charge-to-mass ratio), we were able to get a large enough ${ }^{4} \mathrm{He}^{0}$ background to produce a measurable flux of energetic ${ }^{3} \mathrm{He}^{0}$ neutrals to our analyzer. 
A bounce-averaged Eokker-Planck program (EPPRF) [8] was used to calculate the distribution function $f(E, u, r, t)$, and integrate along a sightine to simulate the charge exchange spectra. It takes into account collisional energy drag, energy diffusion, and pitch-angle scattering, and uses the FRANTIC code[9,10] for calculating neutral density profiles. The cross sections in this part of the program were modified to allow it to calculace the ${ }^{4}$ He neutral density profile. The ionization cross section included not only electron impact ionization but also single charge exchange ${ }^{4} \mathrm{He}^{++}$ $+{ }^{4} \mathrm{He}^{\mathrm{O}}$ - ${ }^{4} \mathrm{He}^{+}+{ }^{4} \mathrm{He}^{+}$. A bounce-averaged quasilinear operator $[8,: 1]$ was used to calculate RF-generated energetic ions. This operator is an extension of Stix's work[12] to include properly the preferential neating of some trapped particles and their production by the RF.

The energetic $3 \mathrm{He}^{\mathrm{O}}$ must be reionized before it can be analyzed. As suggested by Post, Grisham, and Medley, $\mathrm{H}_{2}$ was used in the stripping cell instead of the usual He, because it has a higher cross section for ionizing helium. Operation at higher stripping cell pressures than the original design (increasing the gauge reading from 0.5 to 3.5 millitorr, with a gauge factor of 2.0 for hydrogen) also improved the stripping efficiency. Measurements were also made with a $50 \AA$ carbon foil[13], but the count rate was lower than for a gas stripping cell, probably because of larger scattering losses.

It was necessary to run the charge exchange analyzer at very high magnetic fields (approximately 4.7 kilogauss) to measure $3 \mathrm{He}$ up to $150 \mathrm{keV}$, since the analyzer determines the energy of the incident particles by their radius of curvature in a magnetic field, and the gyroradius of the singly charged $3 \mathrm{He}^{+}$emerging from the stripping cell is larger than that of a proton with the same energy. Obtaining an adequate signal-to-noise ratio for the ${ }^{3} \mathrm{He}$ measurements was difficult, not only because the charge exchange cross section 
is a factor of ten less and the stripping efficiencies are slightly worse than for hydrogen, but also because the X-ray background noise was fairly high, perhaps because of the larger breakdown voltages needed to start up a helium plasma. Nonetheless, data were successfully obtained up to $150 \mathrm{keV}$ for several viewing angles (Fig. 2).

The ${ }^{3} \mathrm{He}$ spectra measured at three different viewing angles are compared in Fig. 2 to the Fokker-Planck code results assuming a peaked RF power profile $\left(E^{+}\right.$proportional to $\left.\left(1-r^{2} / a^{2}\right)^{1 / 2}\right)$, and in $E$ ig. 3 to calculations for a hollow power profile. The total af power to the 3 He was $2.1 \mathrm{MW}$ after $15 \%$ coupling losses. The $3_{\mathrm{He}}$ concentration $\left(n_{3_{\mathrm{He}}} / \mathrm{n}_{\mathrm{e}}\right)$ as measured by the density rise during the ${ }^{3} \mathrm{He}$ gas puff is $6 \%$. Inlike the case of hydrogen minority heating, one might expect this to be a good measurement because the walls are less likely to absorb helium than hydrogen, a conjecture verified by the measurements of Chrien et al.[14]. Other parameters used for these simulations include: $z_{\text {eff }}=3.4, z_{I}=6.7$ (which may seem low because it includes contributions from the $\left.{ }^{3} \mathrm{He}\right), a=37 \mathrm{~cm}, \mathrm{~A}=136 \mathrm{~cm}, B_{\text {tor }}=31.04 \mathrm{kilogauss,} \mathrm{B}_{\text {res }}$ $=143.4 \mathrm{~cm}, I_{p}=450 \mathrm{kA}, V_{2}=2.3 \mathrm{~V}$, and $\mathrm{k}_{\|}= \pm 0.07 \mathrm{~cm}^{-1}$.

Comparing the $3_{\mathrm{He}}$ spectra of Figs. 2 and 3 to the hydrogen spectra of Fig. 4 (the Fokker-Planck simulations of Figs. 3 and 4 assuming the same hollow RF power profile) leads to a number of interesting observations. In both cases, the largest charge exchange flux is observed not at the most perpendicular angle, but at an intermediate angle between perpendicular and parallel. This is because ion cyclotron heating tends to produce energetic particles whose banana tips are located near the resonance layer[15], an effect that has been terined "resonance losalization"[16]. The anisotropy between different viewing angles is not as strong as in the hydrogen case, consistent with the higher pitch angle scattering rate of ${ }^{3} \mathrm{He}$. The ${ }^{3} \mathrm{He}$ tail 
is not as energetic as the $H$ tail, and no "negative temperature" is observed at the peak angle. The scatter in the data near $60 \mathrm{keV}$ is thought to be instrumental, due to a change in the sensitivity across adjoining microchannel plates. This problem was corrected after the present measurements were performed. The Fokker-Planck calculations indicate that the fraction of power lost on unconfined orbits is much less for $3 \mathrm{He}$ (about 10\%) than for $H$ (about 75\%). (These hydrogen minority experiments were done in a low density and low minority concentration regime, which produced an extremely energetic tail that was poorly confined).

The Fokker-Planck calculations ignore radial transport of fast ions, while there are a number of mechanisms (e. g., sawtooth oscillations, ripple, and large banana width neoclassical effects) which may be playing a very important role. Instead, fast ion transport would be seen as a broadening of the RF power proflle in the present model, and the shape of this profile is varied to fit the charge exchange neutral spectrum. The peaked power simulation predicts a perpendicular spectrum with a slightly hotter tail than observed, although the calculated peak angle slope is approximately correct. The broad power simulation (Fig. 3) produces the proper perpendicliar slope, but the peak slope is much too energetic. The best fit to the 3fe data lies between these two extremes.

While it was necessary to assume a hollow power profile to fit the $H$ spectra (Fig. 4), the ${ }^{3} \mathrm{He}$ spectra do not seem to require as much broadening. Not only are unconfined orbit losses smaller for the $3_{\text {He case, but the radius }}$ of the $q=1$ surface is also smaller (measured to be $r=9 \mathrm{~cm}$, from the inversion radius determined by the electron cyclotron emission diagnostic, versus $r=15 \mathrm{~cm}$ for the $H$ case). This is because the toroidal field is aigher while the plasma current is the same. These observations do not 
provide solid evidence that the broad hydrogen RF profile is due to sawtooth and edge drag transport, but they are consistent with this interpretation. On the other hand, low power hydrogen spectra [8] seemed to indicate a broad RE power profile in a case of negligible unconfined orbit losses. A more definite conclusion which can be drawn from these data is that 3 He minority heating is more efficient than $H$ minority heating because ${ }^{3} \mathrm{He}$ is more collisional, transfers more of its energy to ions instead of electrons, and suffers less from unconfined orbit losses.

In conclusion, the utility of charge exchange neutral particle measurements for the study of 3 He minority ICRF heating has been demonstrated through the first direct measurements of the energetic ion tail, and the results show features consistent with previous measurements during $H$ minority ICRE measurements and quasilinear theory. Other diagnostios useful for studying ${ }^{3}$ He ICRF heating include radial fusion product measurements (as demonstrated in PLT) $[3,4]$ and charge exchange recombination spectroscopy $[17,18]$. Although nulti-MeV, $z>2$ neutral beams are necessary to diagnose $3.5 \mathrm{MeV}$ alpha particles (because of the sharp degrease in the charge exchange cross section for relative energies above $200 \mathrm{keV}$ ), the double charge exchange technique we have demonstrated here could use standard neutral beam injectors to measure these particles once they have slowed down to the 50 to $400 \mathrm{keV}$ range. 
Acknowledgments

The authors would like to express their gratitude to the physicists and the technical support staff of PLT, and P. Colestock, J. Hosea, and D. Hwang in particular for their vital role in the ICRF program. They also thank G. Gammel, S. S. Medley, and A. L. Roquemore for their efforts in calibrating, installing, and operating the CENA. This work was supported by the $U . S$. Department of Energy under Contract No. DE-ACO2-76-CHO-3073. 
References

[ 1] Mazzucato, E., et al., 10th Conf. on Plasma Physies and Controlled Nuclear Fusion Research, London, Vol. I, (1984) 433.

[ 2] Wilson, J. R., et al., 6th Topical Conference on RF Plasma Heating, Callaway Gardens, GA, May 1985 (American Institute of Physics, New York, 1985) pp. 28-31.

[ 3] Chrien, R. E. and Strachan, J. D., Phys. Fluids 26 (1983) 1953.

[ 4] Murphy, T. J. and Stracinan, J. D., Nucl. Fusion 25 (1;85) 383.

[ 5] Post, D. E., Grisham, L. R., and Medley, S. S., Nucl. Tech./Fusion 3 (1983) 457.

[ 6] Post, D. E., Mikkelson; D. R., Hulse, R. A., Stewart, L. D., and Weisheit, J., J. Fusion Energy 1 (1981) 129.

[ 7] Roquemore, A. L., Gammel, G., Hanmett, G. W., Kaita, R., and Medley, S. S., Rev. Sei. Instrum. $\underline{56}$ (1985) 1120 .

[ 8] Hammett, G. W., "Fast Ion Studies of Ion Cyclotron Heating in the PLT Tokamak," Ph. D. Dissertation, Princeton University, University Microfilms International No. GAX86-12694, (1986).

[ 9] Towner, H. H., Goldston, R. J., Bull. Am. Phys. Soc. 24 (1979) 1107.

[10] Tamor, S., J, Comput. Phys. 40 (1981) 104.

[11] Kerbel, G. D. and McCoy, M. G., Phys. Fluids 28 (1985) 3629.

[12] Stix, T. H., Nucl. Fusion 15 (1975) 737.

[13] Gott, Y. V. and Motlich, A. G., Nucl. Instrum. Meth. 155 (1978) 443. [14] Chrien, R. E., Eubank, H. P., Meade, D. M., and Strachan, J. D., Nucl. Fusion 21 (1981) 1661 .

[15] Kaita, R., Goldston, R. J., et al., Nucl. Fusion 23 (1983) 1089. 
[16] Hsu, J. Y., Chan, V. S., Harvey, R. W., Prater, R., and Wong, S. K., Phys. Rev. Lett. $\underline{53}$ (1984) 564 .

[17] Fonck, R. J., Goldston, R. J., Kaita, R., and Post, D. E., Appl. Phys. Lett. $42(1983) 239$.

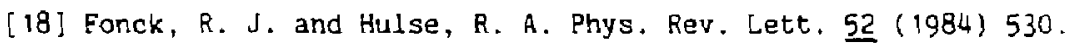


Figure Captions

EIG. 1 Top view of the PLT tokamak and the horizontally scanning charge exchange neutral analyzer. The $3_{\mathrm{He}}$ spectra were obtained at the CENA positions marked PERP (Ferpendicular), PEAK (angle with peak signal), and PAR (parallel or tangential). (86\%0509)

FIG. 2 Measured 3 He spectra compared with predictions assuming a modestly peaked $E^{+}(r)$ profile. (86×0499)

FIG. 3 Measured ${ }^{3}$ He spectra compared with predictions assuming a hollow $E^{+}(r)$ profile. (86x0500)

FIG. 4 Measured hydrogen spectra compared with predictions assuming the same hollow $\mathrm{E}^{+}(\mathrm{r})$ profile used in Fig. 3. (86x0513) 
Vertically. Scanning

\#86 $\times 0509$

Mass Analyzed

Charge Exchange

(MACE) Diagnostic

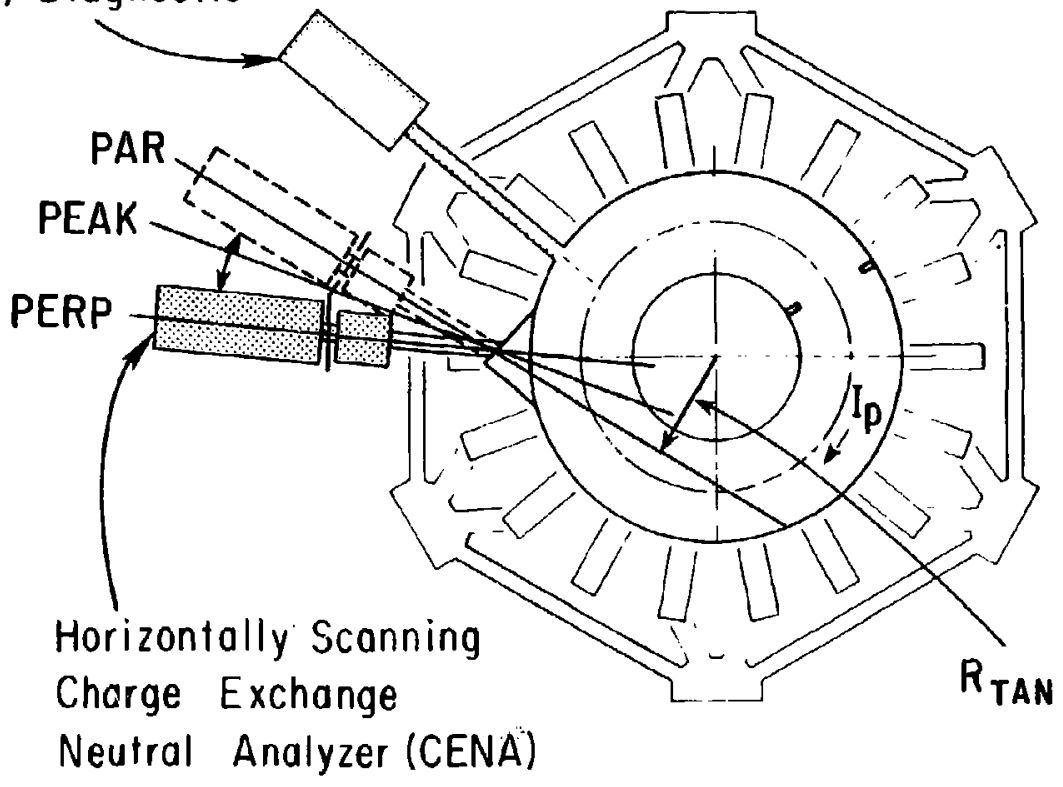




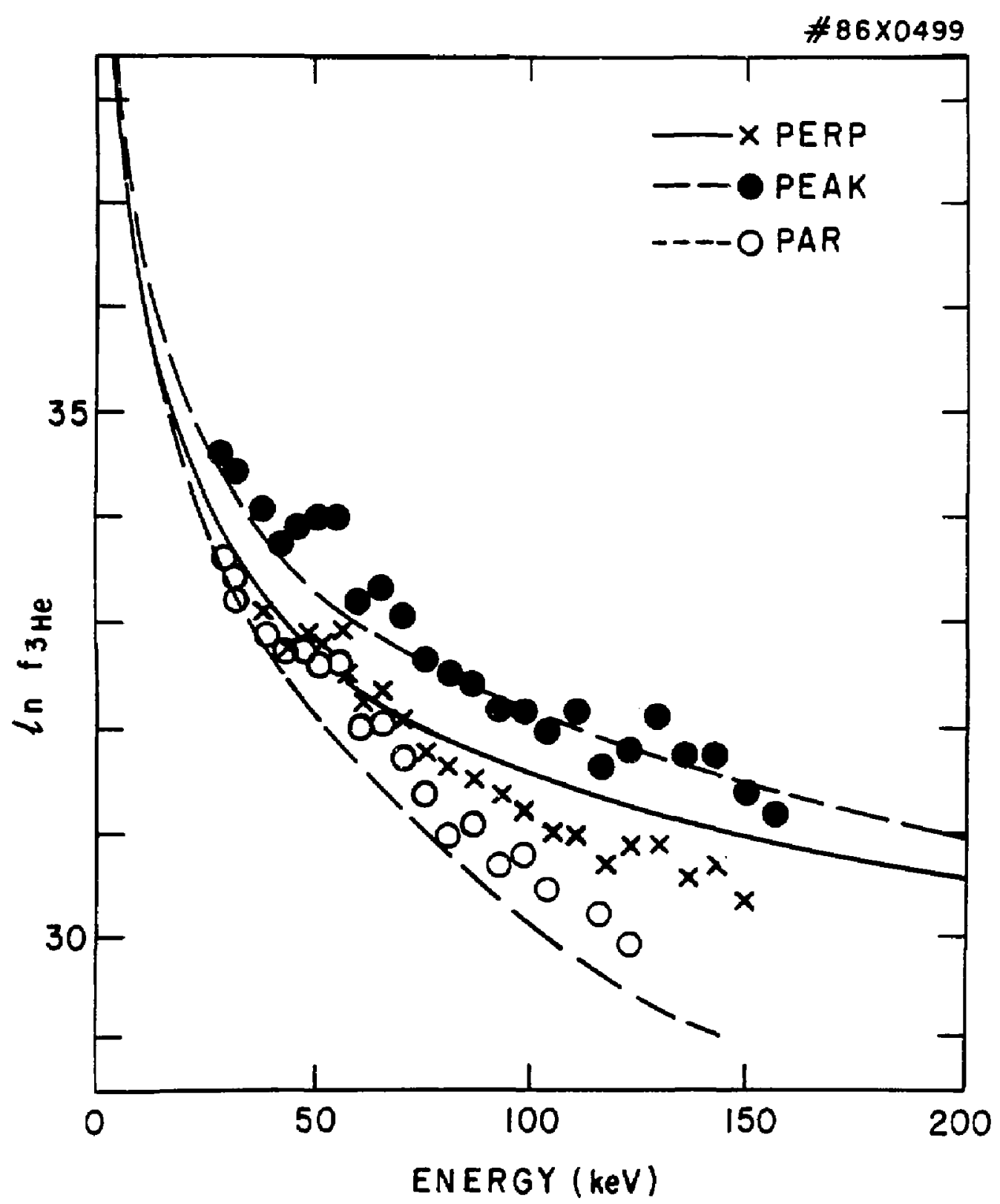

Fig. 2 


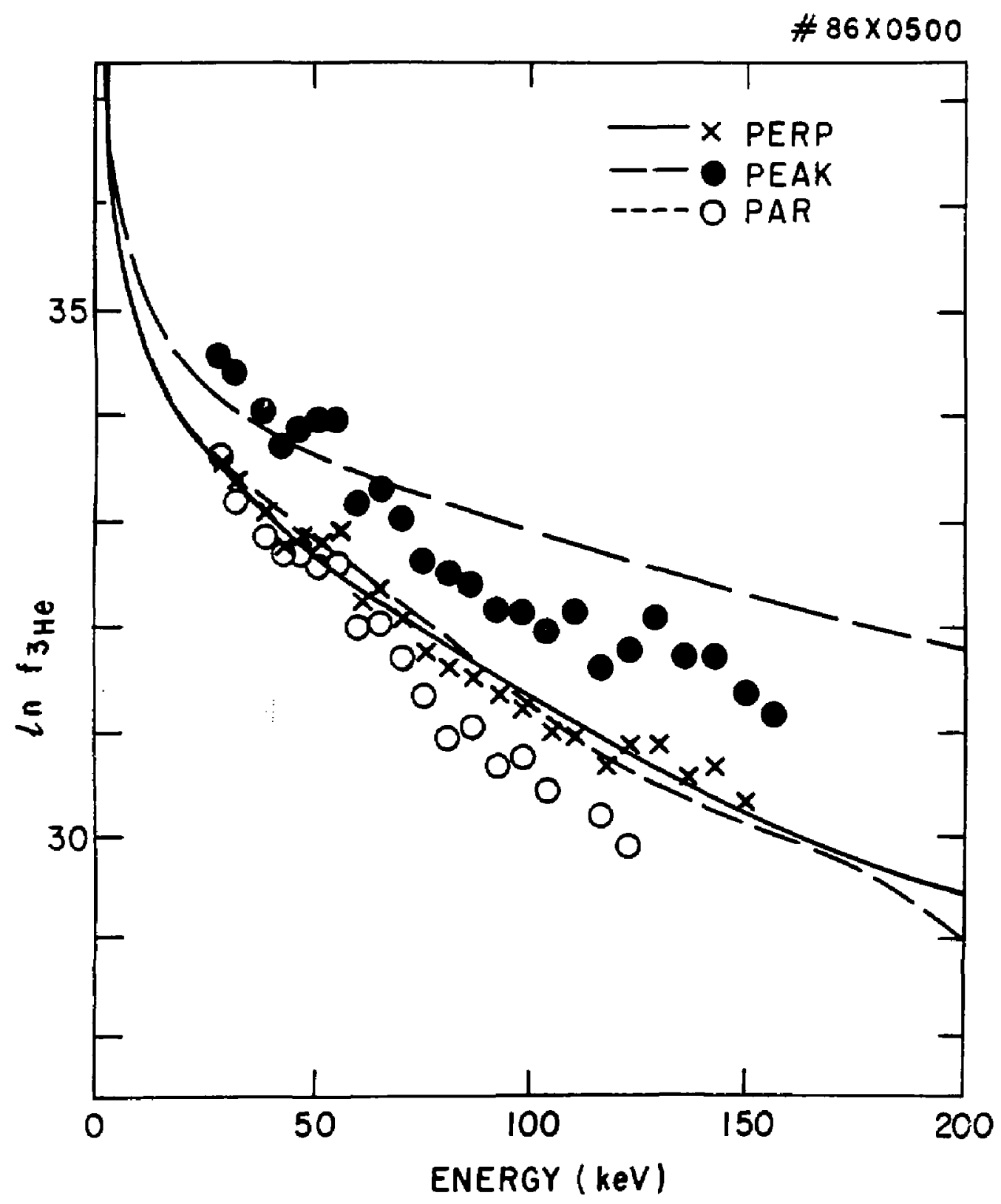

Fig. 3 


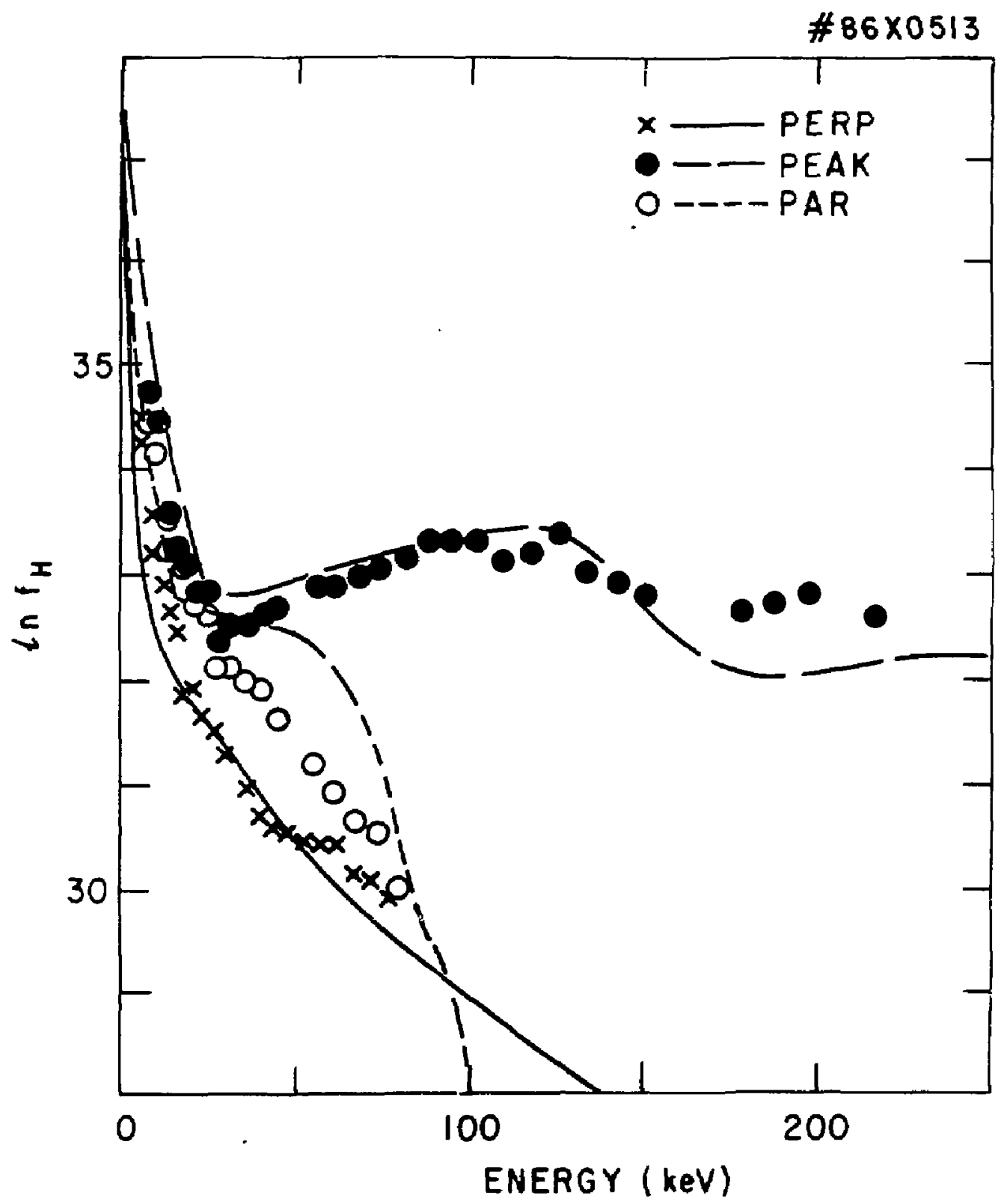

Fig. 4 


\section{EXTERNAL OISTRIBUTION IN ADOITION TO UC-20}

Dr. Frank J. Paoloni, Univ of wollongong, AuSTral I A Prof. M.H. Brennan, Univ Sydney. AuSTRAL IA Plasma Research Lab.. Australian Nat. Univ., AuSTRal IA Prof. I,R. Jones, Flindors Univ., Austral IA Prof. F. Cad, Inst Theo Phys, Austria Prof. He. Heindler, Institut ur Theoretische Physik, Austria M. Goossens, Astronomisch Instituut, BELGIUM Ecole Royale Militaire, Lab de Phys Plasmas, BELGIUM Comission-Eurogean, Dg-XI I Fusion Prog. EELGIUA Prot. R. Boucique, Laboratoriun voor Naruurkunde, BELGIUA Or. P.H. Sakaneka, Instituto Fisica, BRaZIL Instituto de Pesquisas Espaciasi-INPE, BRAZIL Documents Office, Atomle Energy of Canada Linited, CANADA Dr. M.P. Bachynski, MPB Tecnnologies, Inc., CANAOA Dr. H.H. Skarsgard, University of Saskatchawan, CAMADA Dr. H. Sarnara, University of British Colunbia, CANADA Prof. J. Teichmann, Univ. of Montrobl, Carada Prof. S.R. Sreanivasan, University of Calgary, Canada Prof. Tudor H. Johnston, INAS-Energie, CANADA Dr. C.R. Janes, Univ, of Alberta, CANADA Dr. Peter Lukac, Komanskemo Univ, C2ECHOSLOVAKIA The Librarian, Culha Laboratory, ENCLAND The Librarian, Rutherford Appleton Laboratory. ENGLAND Mrs. S.A. Hutchinson, JET Library, ENGLAND C. Houttet, Lab. do Phys ique des Mllieux Ionises, Frarce J. Radat, CEN/CADARACHE - Bat s06, FRANCE Uniy. of loannina, Library of Physles Dept. GReEc Dr. Ton Mual, Acadoey Bibliographic Ser., HONG KCHB Preprint Library, Hungarian Mcadery of Sciences, HunenRr Or. A. Dasguata, Saha Inst of Nuel. Phys.. INuiA Dr. P. Kaw, Institute for Plasma Research, INDIA Dr. Philip Rosenau, Israel Inst. Tech, ISRAEL Librarian, Int'I Ctr Theo Phys, ITALy Prof. G. Rostagni, Univ Di Padova, ITALY Miss cielio on Palo, Assoc EURATON-EnEA, ITALY Biblioteca, Instituti ci Fisica del Plasma, ITALt Dr. H. Yamato, Toshiba Res \& Dev, JAPAN Prof. 1. Kawakani, Atomle Energy Res. Institute, JAPAN Prof. Kyoji Nishikana, Univ of Hiroshima, JAPAN Diroc. Dapt. Largo Toxamak Res. JAER!, JAPAN Prof. Satoshi Itoh, Kyushu Univarsity, JAPAN Research Info Center, Nagoya University, JAPAN Prof. S. Tanaka, Kyoto University, JAPAN Library, Kyoto University, JAPAN Prof. Nobuyuki Inoue, University of Tokyo, JAPAN 5. Mor i, JAER1, JAPAN

Librarian, Korea Advanced Energy Res. Institute, KOREA Prof. D.I. Choi, Adv. Inst Sci \& Tech, KOAEA Prof. B.S. Liley, University of Haikato, NEW ZEALANO Institute of Plasma Physics, PEOPLE's REPUBLIC OF CHINA Librarian, Institute of Phys.. PEOPLE's REPUELIC Of CHIMA Library. Tsing Hua University, PEOPLE's REPUELIC OF CHINA
Z. Li, Southwost Inst. Physics, PEOPLE's REPUBLIC Of OHINh Prof. J.A.C. Cabral, Inst Suderior Tecnico, DORTUGAL Or. Octavian Petrus, AL I CUZA University, ROMANIA Dr. Johąn de villiers, Fusion Studies, AEC, SO AFRICA Prof. M.A. Hellberg, University of Natai, So AFRICA C.I.E.M.A.T., Fusion Div. Library, SPAIN Dr. Lennart Stenfla, University of UMEA, SHEDEN Library, Royal Inst Tech, SwEDEN

Prof. Hans Withelmson, Chalgars Univ Teeh, SHEDEN Cantre Phys des Plasmas, Ecole Polytech Fed, SWITZERLAND Blbliotheak, Fom-inst Voor Plasma-Fysica, THE NETHERLANOS Dr. D.D. Ryutov, Siberian Acad Sei, USSR

Dr. G.A. El iseev, Kurchatov Institute, USSR

Dr. Y.A. Gluknikh, Inst Eloctrophysical Apparatus, USSR Dr. Y.T. To ut, Inst, Phys. Tech, USSR

Dr. L.M. Kovrizhnykh, Ingtitute Gen. Physics, USSR Nuclear Ras. Establishment, Julich Ltd., w. GeRMANY Bibiliothax, Inst. Fur PIasmatorschung, W. GERMANY Dr. K. Sebindler, Ruhr Univorsitat Bochum. W. GEFManY ASDEX Roading An, IPP/Max-Planck-Institut fur

Plasmaphys ik, W. Gerahuny Librarian, Maxtianck Institut, W. GERMANY Prot. R.K. Jomev, Inst Phys, rUGoSLAVIA 